\title{
Comparison of the Use of Conventional and Digital Visualization Technologies in Environmental Design Education
}

Emine Tarakci Eren, Tugba Düzenli and Serap Yılmaz

Karadeniz Technical University, Department of Landscape Architecture

\section{Abstract}

The rapid advances in computer technology rendered the use of the new technologies in professional disciplines such as visual arts, design, architecture and planning, where visualization is utilized prominently i.e. is a requirement. However, applications such as using conventional design tools and graphical presentation techniques, sketching, drawing plans, sections, perspectives on paper and creating models are still used in landscape architecture, architecture, interior architecture or in departments that rely on planning. Digital technologies, on the other hand, are used as supplementary tools. The aim of the present article was to determine the methods utilized predominantly in different stages of environmental design studio in landscape architecture education and the advantages and disadvantages of the utilized conventional and digital presentation techniques, and to compare the developing visualization software. In this context, the level of satisfaction of the students with these methods was determined. The study was conducted with students in the Landscape Architecture Department attending Karadeniz Technical University (KTU). The study findings demonstrated that the satisfaction levels of architecture students with digital technologies were higher when compared to conventional methods due to the facilities and superior qualities provided by the digital technologies.

Key words: conventional and digital visualization; environmental design studio; technology; satisfaction level.

\section{Introduction}

Teaching methods are scientifically and experimentally proven ways of efficient communication between professors and students in the process of transferring and 
acquiring knowledge and skills, developing competencies and facilitating all other personality development potentials in the teaching and learning process (Duh \& Zupančič, 2011). In the century we live in, where the use of information technologies expanded, their use in the field of education has also increased due to the improvement in productivity and opportunities created by these technologies (Korkut \& Özyavuz, 2016a; Mc Cullough et al., 1990). Computers are useful for making the abstract concepts concrete on the screen and for facilitating the learning process (Baki, 2002). As a matter of fact, many of the recent studies proved that computer has a positive effect on students' learning (Barkatsas, Kasimatis, \& Gialamas, 2009; Qing \& Xin, 2010; Tjaden \& Martin, 1995). The digital technology revolution that changed the conventional drawing forms has been experienced (Yıldırım, Özen \& İnan, 2008). It was observed that products created with digital technologies closely resembled the reality when the products created with these software in all design disciplines, and especially in landscape architecture education, were compared with the products obtained with conventional methods (Akipek, 2004; Çolakoğlu \& Yazar, 2007; Nailer \& Castle 2012; Orhon, 2012; Yllmaz et al., 2017). Digital methods, however, have some disadvantages when compared to conventional methods.

The software and hardware that were developed based on computer technology have become significant tools for designers in developing their 3D images (Aybar, 2015; Burmabiyık, 2015; Chalmers, 1981; Karadağ, 2011). Furthermore, the visuals designed within the digital environment are preferred for their movement and expressiveness. Digital visualization techniques are utilized where conventional methods fail. Thus, the use of digital visualization should not be differentiated from the use of conventional methods. Perception of open spaces with digital narrative techniques, the concept of scale, and presentation of inputs such as light, shadow and time could produce significant and successful results. In other words, design elements in environmental design projects often include living elements, i.e. plants. Since plants are living elements, they grow and change over time. These changes, which will be observed in projects over time, are expressed as the fourth dimension. Animations that could be designed with digital narrative techniques could introduce the time concept in environmental design projects. With conventional methods, this possibility is reduced. Unlike conventional methods, tools such as computer, printer and software are needed to utilize these techniques. Visualization software is preferred because of their advantages such as saving time, reducing costs, ease of editing, easy data storage, possibility of drawing with zero mistakes, rapid reproduction of drawings and easy generation of new alternatives (Eceoğlu, 2012; Kalayc1, 2006; Mayer \& Sims, 1994; Uğur \& Özgür, 2003). Furthermore, it is important to separate digital learning from the sensory modality (visual, aural, olfactory, tactile and taste information) chosen to represent instructional methods (Clark \& Feldon, 2005; Lauc et al., 2013).

When we talk about design education, the first thing that comes to mind is indoors and interior design (Batmaz, 2013). Since outer spaces are perceived as the combination of trees and buildings, the perception and design of spaces between these elements as 
a volume are difficult at first sight for people who are not professionals. Vocational education and experience is required to perceive these volumes as spaces. A good environmental design preserves and improves the health of all living organisms, and the advantages and disadvantages of natural events are considered in conjunction. A successful design should consider larger environmental issues that affect the region, the country, and even the world. Such a design approach is often referred to as environmental design (Booth \& Hiss, 2008; Melby \& Cathcart, 2002).

In environmental design education, the training starts after the project field is identified. In the stage of research analysis, students conduct land survey and land analysis while in the design stage, they conduct land use, function diagram, bubble diagram, form, preliminary design, option generation and precise design studies, and in the project detail stage, they prepare floor cladding, planting plans, construction details and sections and elevations (Alpak et al. 2017; Düzenli \& Alpak, 2016; Kahraman, 2006; Tarakci Eren \& Var, 2016). Students could do these steps by visualizing their thoughts and with the ability of cognitive rotation (Maier, 1994).

The types of presentation used by students for the visualization of environmental design projects are categorized in two groups: conventional and digital presentation techniques (Al-Kodmany, 1999; Ertan 2016; Goldschmidt \& Smolkoy, 2006; Jones, 1992; Linn, 2000; Near, 2012; O-Neill, 1994; Paar, 2006; Shaw, 1994)

Conventional presentation techniques are:

a) two-dimensional drawings on paper (plan, section, elevation); three-dimensional drawings on paper (perspective); three-dimensional models.

b) Digital presentation techniques are: two-dimensional drawings created with digital media (plan, section, elevation); three-dimensional models created with digital media; animation, realistic images created with digital media.

\section{Conventional Presentation Techniques Utilized in Environmental Design Stages}

During the environmental design process, abstract images about the solution of a design problem are formed in the mind of the designer (landscape architect, student). The first step that a student utilizing the conventional presentation techniques should take is to visualize images formed in her or his mind using tools such as paper, pencil or models (Table 1). Drawing is the visualization of all or parts of an architectural element using plans, sections, elevations or perspectives according to the technical drawing rules.

\section{Digital Presentation Techniques Used in Environmental Design Stages}

Digital presentation techniques used in the environmental design studio process are architectural software used to generate stationary and moving visuals, pixel-based, 
Tarakci Eren, Düzenli and Yllmaz: Comparison of the Use of Conventional and Digital Visualization ...

Table 1

Conventional presentation technique examples

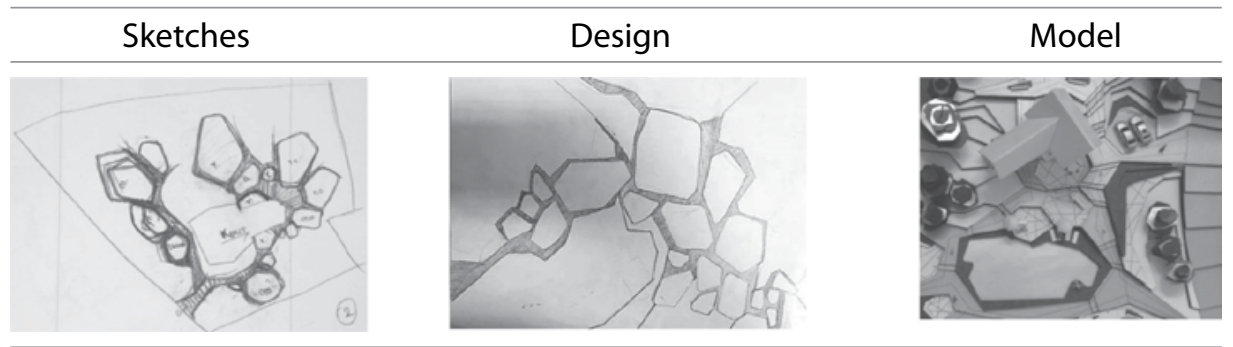

\section{Section}

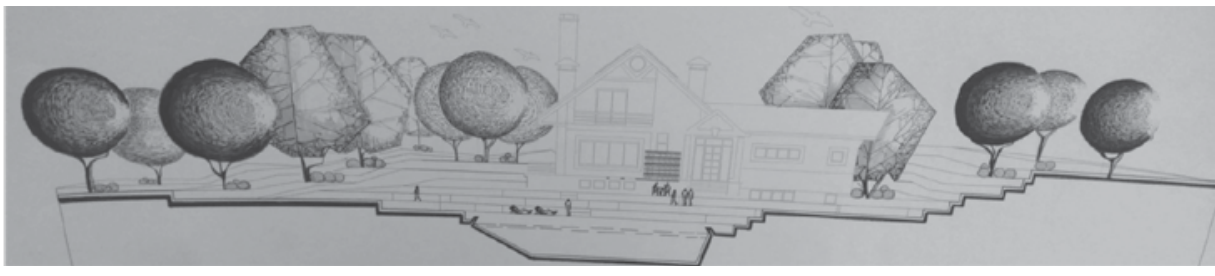

Table 2

Digital presentation technique examples

\begin{tabular}{lll}
\hline Land survey & Land use plan & Exact design plan \\
\hline (a) &
\end{tabular}

\section{D Modeling}
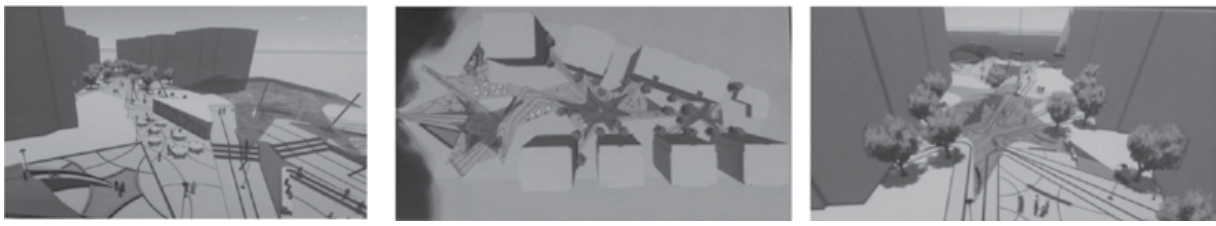

\section{Section}

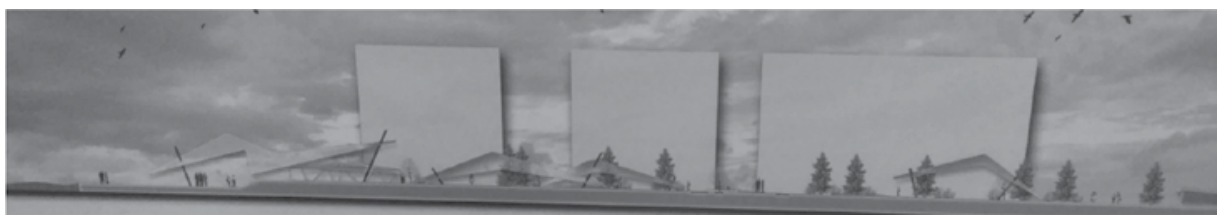


vector-based and object-based software (Donath \& Regenbrecht, 1996; Felleisen, 2001; Hughes, 2014; Kalay, 2004). Vector-based software is used to produce line drawings. Vector-based software in architectural design is used for two-dimensional drawings, three-dimensional modeling and three-dimensional cladding, material matching and lighting. In vector-based software, two-dimensional drawings (plan, section and elevation) include line elements. Here, the lines can be linear or spline. In environmental design projects, spline lines are frequently used. Three-dimensional spatial design is modeled through lines, nodes where the lines intersect, and by closing the surfaces of areas created by these lines, respectively. In addition to the 3D design models produced with vector- or object-based software, photorealistic images of environment design products could be obtained by matching textures obtained with cameras, lighting and building materials (Table 2).

\section{Materials and Methods}

In the present study, user preferences were determined using the survey technique. The questionnaires were completed by 280 students (Table 3 ) attending the Landscape Architecture Department at Karadeniz Technical University, Faculty of Forestry (265 undergraduate and 15 graduate (master and $\mathrm{PhD}$ ) students). In the survey, students were asked the following questions:

- which computer software they used,

- which presentation techniques they preferred in environmental design studio stages,

- their assessment of conventional and digital presentation techniques with respect to time,

- their assessment of the images obtained with the abovementioned techniques with respect to "verisimilitude," "image quality," "easy and long term storage," and "movement"

- and, their satisfaction levels with these methods.

Table 3

Demographic structure of the students

\begin{tabular}{|c|c|c|c|c|c|c|c|c|c|}
\hline \multirow{2}{*}{\multicolumn{2}{|c|}{$\begin{array}{l}\text { Demographic } \\
\text { structure }\end{array}$}} & \multicolumn{4}{|c|}{ Undergraduate } & \multirow{2}{*}{ Graduate } & \multirow{2}{*}{ Total } & \multirow{2}{*}{$x^{2}$} & \multirow{2}{*}{$\mathrm{df}$} \\
\hline & & Freshman & Sophomore & Junior & Senior & & & & \\
\hline \multirow{2}{*}{ Gender } & Female & 39 & 36 & 35 & 33 & 9 & 152 & \multirow{2}{*}{.411} & \multirow{2}{*}{5} \\
\hline & Male & 34 & 30 & 30 & 28 & 6 & 128 & & \\
\hline
\end{tabular}

$\mathrm{x} 2$ - Chi-Square determines whether there is an association between categorical variables $\mathrm{df}$-The degree of freedom associated with the sources of variance.

\section{Results}

Results Pertaining to the Computer Software Used in Environmental Design Studio Education

Survey data on students' use of computers in environmental design and presentation studies demonstrated that a small number of students (7\%) occasionally used 
computers, while the majority (93\%) actively used computers. The preferences of the survey participants about the software they used in design studies are presented in Figure 1. It was observed that all students participating in the survey preferred popular software such as AutoCAD, Photoshop and Sketchup in their environmental design studies, and certain students also preferred Archicad, 3ds Max and Lumion software.

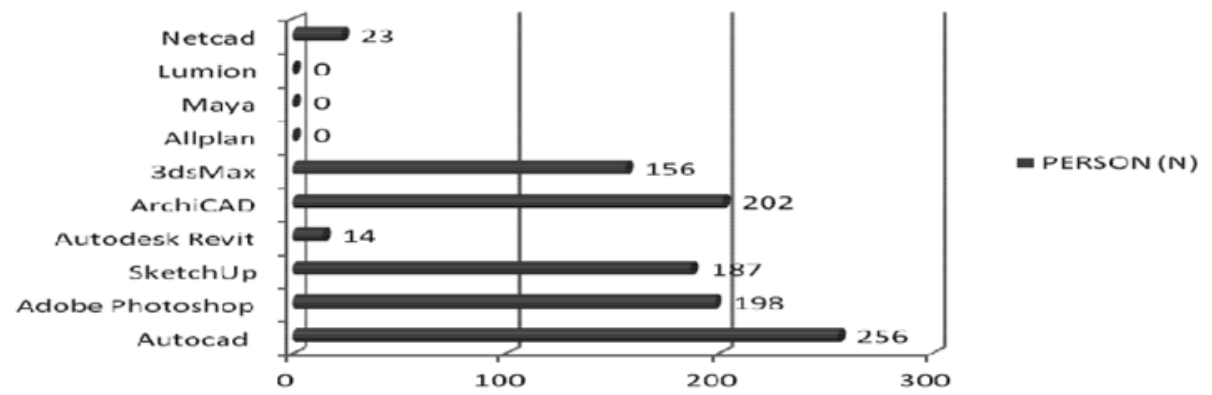

Figure 1. The software students preferred in environmental design studies

\section{Results of the Presentation Techniques Preferred by Students in Environmental Design Studio Stages}

Today, there is a consensus that conventional teaching methods are inadequate, and computer technologies and software started to be utilized in education, and a transition to conventional + technological education was realized (Zor, 2006). Nevertheless, previously, use of computers in different stages of design training was due to the economic and therefore technological limitations prevalent in colleges. Today, however, these technologies are widely used. The responses given by students to the question related to the technique they used in the environmental design studio are presented in Figure 2.

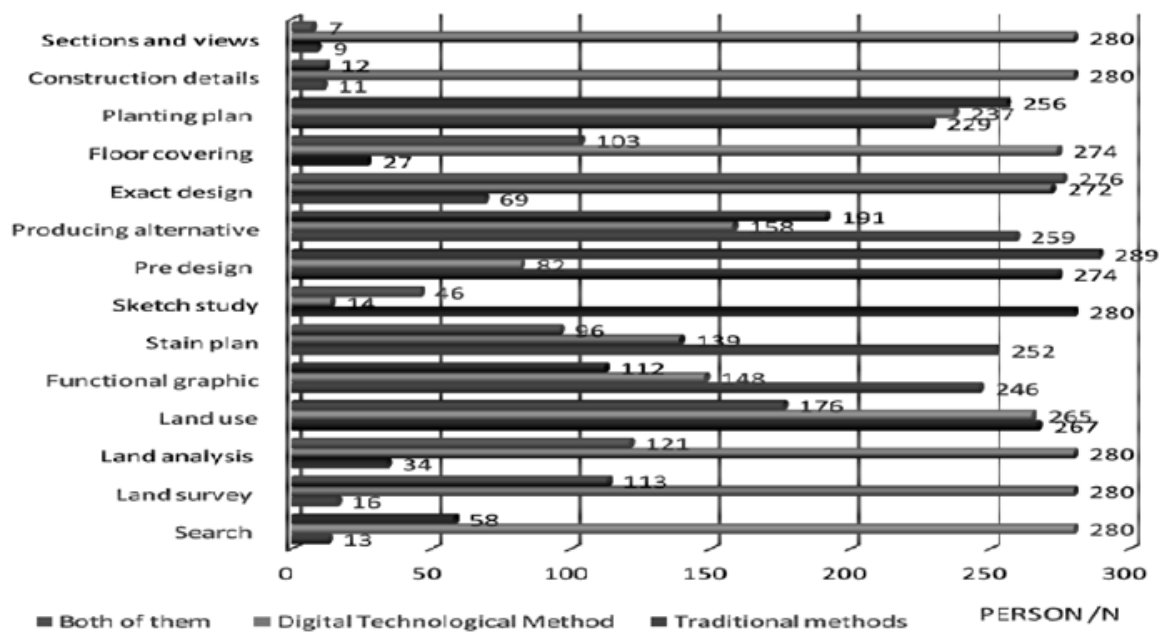

Figure 2. The presentation techniques preferred in the environmental design studio 


\section{Results of the Assessment of the Techniques Based on Time in Environmental Design Studio Process}

The time that landscape architecture students spend in materializing abstract designs they imagine varies depending on the students' presentation techniques. The responses given by students about the time they spend in the environmental design studio process are presented in Figure 3 based on the results obtained in the survey.

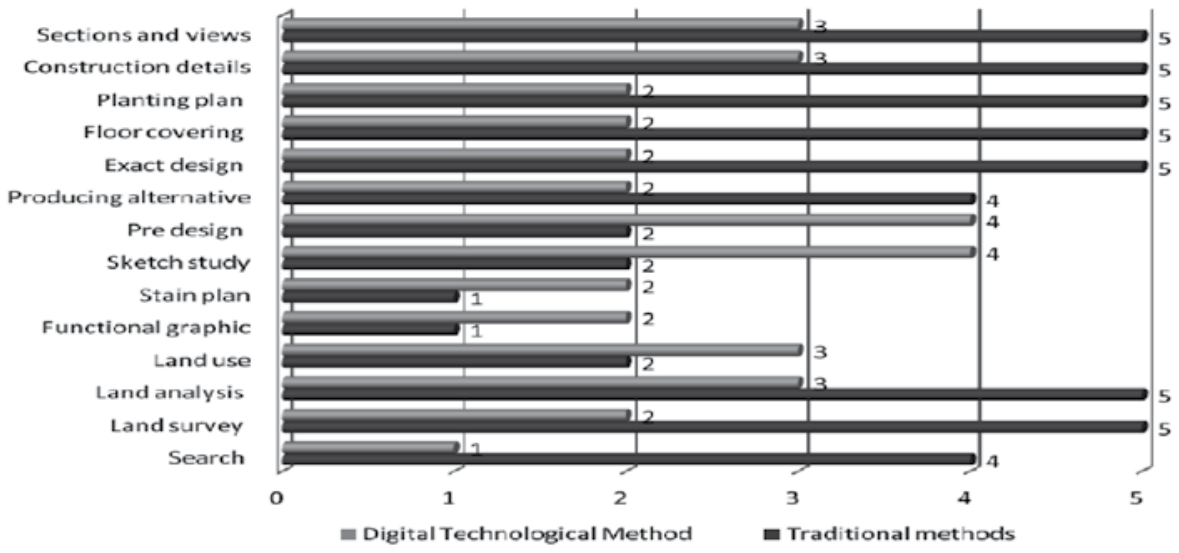

1) 0-100 minutes, 2) 101-200 minutes, 3) 201-300 minutes, 4) 301-400 minutes, 5) 401-over minutes

Figure 3. Assessment of the techniques with respect to time

Generally, digital presentation techniques are completed in a shorter time when compared to traditional methods, but this is not the case at every stage of the environmental design studio process. Students are slower when they use conventional methods to draw more accurately and precisely. It was observed that they can draw faster with digital methods due to the precision and accuracy of the computer software. Furthermore, the use of objects (doors, windows, furniture, etc.) that were previously created and stored in object libraries in digital methods shorten the time required for drawing. Based on the assessments by landscape architecture students, conventional presentation techniques take less time to complete a function diagram, bubble diagram, sketch and preliminary design stages when compared to digital presentation techniques. Digital presentation techniques take less time to complete research, survey, analysis, option generation, final design, hard floor-soft floor, planting, construction-detail and section-elevation drawing stages when compared to conventional presentation techniques. Also, based on the students' assessments of environmental design studio stages, it was determined that conventional presentation techniques were more advantageous since they shortened the time to complete a function diagram, bubble diagram, sketch and preliminary design stages when compared to digital presentation techniques, while digital presentation techniques were more advantageous since they shortened the time to complete research, survey, analysis, option generation, final design, hard floor-soft floor, planting, construction- 
detail and section-elevation drawing stages when compared to conventional presentation techniques.

\section{Results of the Assessment of Techniques with Respect to Verisimilitude of Images Obtained in the Environmental Design Studio Process}

Verisimilitude in environmental design projects is obtaining near-realistic simulations via coating the design with material and assignment of light and shadow to the design. In visuals obtained with conventional methods, material and lightshadow effects in two-dimensional drawings could only be expressed through hatching or painting. In 3D drawings and models, auxiliary tools that were assigned with a material texture are used. In digital methods, however, material could not be assigned to two-dimensional drawings created with vector-based software, but threedimensional models provide successful results since they enable material coating, light and background assignment (objects such as trees, people, sky).

Students are asked to assess digital and conventional presentation techniques for each stage of the environmental design studio by assigning a score between 1 and 5 ( 1 very weak, 2 weak, 3 intermediate, 4 good, 5 very good). The arithmetic mean of the responses was calculated. The result of the assessment of landscape architecture students about the most realistic method during the stages of the environmental design studio are presented in Figure 4. As a result, it was determined that images obtained with digital methods were more realistic according to the students.

\section{Digital Technological Method \\ Traditional methods}

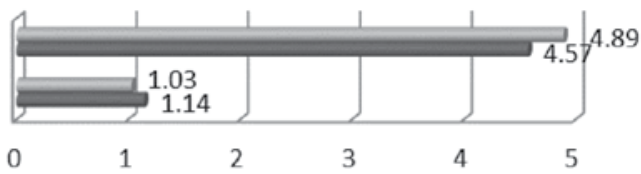

Mobility and impression

\section{Results of the 'Easy Long-Term Storage' and 'Movement- Expressiveness' of the Images Obtained in Environmental Design Studio Process}

Storage is the ability to store images (information) related to the design. Since both the drawings and perspectives created with conventional methods are on paper, and the models are easily perishable presentation tools, they require large storage areas. Digital methods are preferred by landscape architecture students since the generated images are stored in "bytes".

Movement and expressiveness is related to the design of a video or animation with environmental design models, 2D and 3D images. Several factors such as the transition speed between the scenes, filming style and camera angle could be adjusted. The closer the $2 \mathrm{D}$ and $3 \mathrm{D}$ images created with this method are to reality, the more 
impressive the animation or video recordings are. Thus, digital methods are found to be more successful based on 'movement and expressiveness' by Landscape architecture students in environmental design studio. Students were asked to rate the digital and conventional presentation techniques used in environmental design studio course based on easy and long-term storage and movement, and expressiveness between 1 and 5 ( 1 very poor, 2 poor, 3 intermediate, 4 good, 5 very good). The arithmetic mean of the responses was calculated and a graph was plotted (Figure 5).

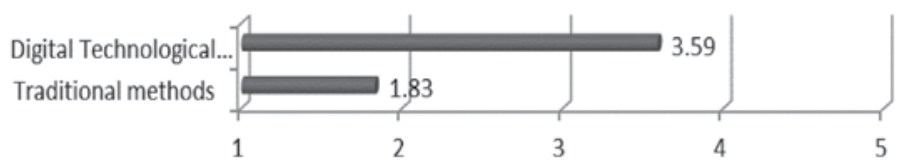

Figure 5. Assessment diagram for the images based on 'easy and longterm storage' and 'movement and expressiveness'

\section{Results of the Satisfaction Levels of Students with the Techniques Used in Environmental Design Studio Stages}

In the surveys conducted with the students, they stated that they were not satisfied with conventional methods since these methods required a long time and effort, produced low quality images, had limited verisimilitude capability and were difficult to revise and create new alternatives $(M=1.83)$. On the other hand, students stated that they were satisfied with the digital methods due to their speed, time requirement, diversity and visual quality, and also determined the level of satisfaction with this method $(M=3.59)$. The students were asked to evaluate the methods based on the environmental design projects they produced during their education using conventional and different digital media (Figure 6). Accordingly, each student used a five-point rating scale (1 very poor, 2 poor, 3 intermediate, 4 good, 5 very good). Assessments based on the criteria for each presentation technique were determined as follows in Figure 6.

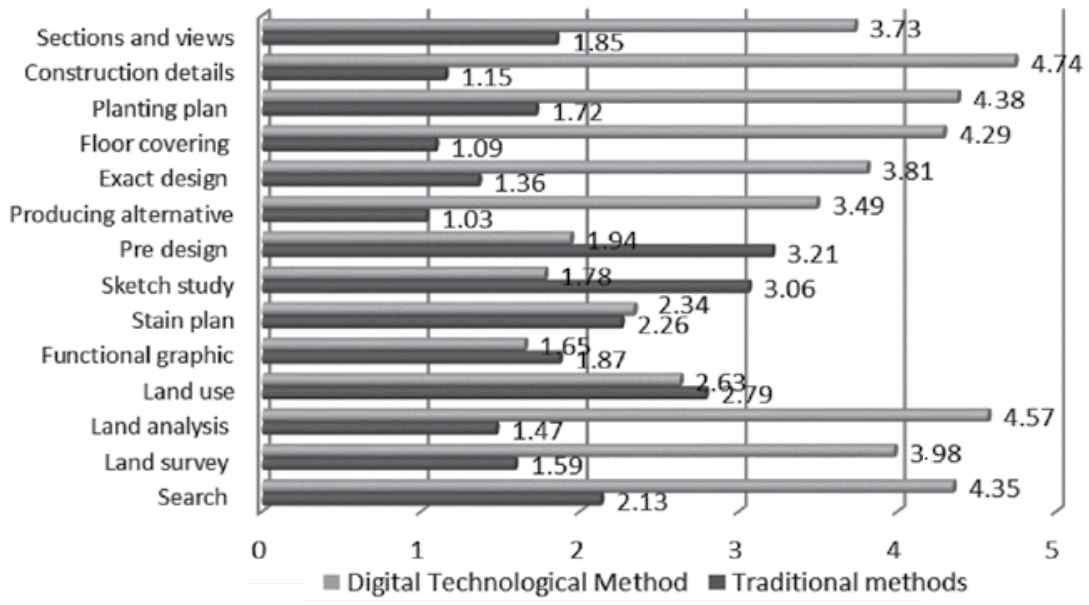

Figure 6. Satisfaction with the techniques 


\section{Comparison of Satisfaction with the Techniques and Image "Easy Storage" and "Movement - Expressiveness" Results}

At this stage, the satisfaction with the presentation techniques and the "easy storage" and "movement-expressiveness" of the images obtained with these techniques were compared.

The variance and skewness-kurtosis values of the data on the answers given by students related to the images obtained after the techniques are presented. When we evaluated the easy, movement and satisfaction features of the techniques, skewness (easy: 0.062; movement: 0.022; satisfaction: 0.64) and kurtosis (easy: -1.825; movement: -1.957; satisfaction: -1.987) were determined. George and Mallery (2010) stated that these values show a normal distribution with a value range of +2.00 and -2.00 . According to this, skewness and kurtosis values in the study indicate that the data show a normal distribution.

The conducted ANOVA test demonstrated that satisfaction with the techniques was effective on images being considered as 'easy to store' and 'moving-expressive' (Table 4). However, it was identified that the 'moving-expressive' characteristic of the images contributed more towards satisfaction when compared to the 'easy-to-store' characteristic of the images.

Table 4

The impact of satisfaction on images ANOVA

\begin{tabular}{llccccc}
\hline & & Sum of squares & $\mathrm{df}$ & Mean square & $\mathrm{F}$ & Sig. \\
\hline Easy & Between groups & 1645.714 & 1 & 1645.714 & 8928.000 & .000 \\
& Within groups & 102.857 & 558 & .184 & & \\
\multirow{2}{*}{ Movement } & Total & 1748.571 & 559 & & & \\
& Between groups & 2055.945 & 1 & 2055.945 & 27141.596 & .000 \\
& Within groups & 42.268 & 558 & .076 & & \\
& Total & 2098.213 & 559 & & & \\
\hline
\end{tabular}

\section{Conclusions}

Similarly as in every other field, digital technology is used extensively in landscape architecture today. Naturally, digital technologies play a significant role in landscape architecture education as a result. These technologies are used in combination with conventional design visualization methods. At the Karadeniz Technical University, Department of Landscape Architecture, traditional and digital presentation techniques are utilized in several courses in addition to environmental design studios. In environmental design education, the advantages of digital presentation techniques compared to conventional presentation techniques were determined as follows.

The production and revision of the images are realized within a shorter time with digital media when compared to the conventional methods. A greater number of alternatives could be designed with less effort with digital methods compared to conventional methods. The same model created on the computer could be used to 
produce two-dimensional drawings, photo-realistic images, animations, and walkthrough simulations. Digital visualization techniques provide more successful results in expressing inputs such as three-dimensional presentation, spatial perception, scale, texture, shadow, light and time where conventional methods fail. More advanced models could be easily created with digital models when compared to conventional methods such as drawings or models, thus enabling interactive sharing of more information. Unlike conventional presentation techniques, the fact that computer generated models are three-dimensional and could be observed from the desired angle is a significant advantage. Conventional visualization training takes longer than computer aided visualization training and requires more class hours in the course schedule.

Along with the comparison of conventional and digital visualization tools, the preference of one presentation technique over the other during the environmental design education course of study at Karadeniz University, Department of Landscape Architecture was also analyzed in the present study. As a result, it was determined that conventional methods were preferred in the function diagram, bubble diagram, sketching, and preliminary design stages in the environmental design studio process, while digital presentation techniques were preferred in research, survey, analysis, option generation, final design, hard-soft floor plan, planting, detail and construction, section and elevation stages.

In conclusion, it was observed that the transformation to the use of information technologies in landscape architecture environmental design education is a compulsory process. However, another significant finding was the fact that conventional presentation techniques are required for the use of digital technologies in the environmental design visualization process. Based on the students' assessments, conventional methods were preferred and used predominantly in the initial project phases of the environmental design studio. The traditional visualization technique includes hand drawings, and the digital drawing technique includes drawings produced using drawing software. It is necessary to commence the student's learning process by enabling them to express themselves with hand drawings (Biggio et al., 2015; Tagliabue, 2011). Since hand movements are followed by the eye while drawing by hand, better brain-hand coordination is established. Hence, students internalize the drawings with the sense of touch; it would be easier for students to create threedimensional images from their thoughts and to rotate them in their mind (Biggio et al., 2015; Tagliabue, 2011). However, when drawing in the digital media, the internalization created by the sense of touch is incomplete. Thus, drawing in a digital media is not sufficient for the acquisition of the skills of presentation and three-dimensional vision that are necessary for the students' development (Biggio et al., 2015; Tagliabue, 2011). In other words, in environmental design studio, the process starts with conventional presentation techniques followed by digital techniques, which are increasingly used along the increasing need for detail. 
Tarakci Eren, Düzenli and Yllmaz: Comparison of the Use of Conventional and Digital Visualization ...

\section{References}

Al-Kodmany, K. (1999). Using visualization techniques for enhancing public participation in planning and design: process, implementation, and evaluation. Landscape and Urban Planning, 45(1), 37-45. https://doi.org/10.1016/S0169-2046(99)00024-9

Alpak, E. M., Özkan, D. G., \& Düzenli, T. (2018). Systems approach in landscape design: a studio work. International Journal of Technology and Design Education, 28(2), 593-611. https://doi.org/10.1007/s10798-017-9402-7

Aybar, A. M. (2015). Sayısal Bilgi İşlemenin Mimarlık ve Tasarım Nesnesi Üzerindeki Etkileri (Doctoral dissertation). Fen Bilimleri Enstitüsü.

Baki, A. (2002). Computer-assisted mathematics for learners and instructors. Istanbul: Ceren press.

Barkatsas, A., Kasimatis, K., \& Gialamas, V. (2009). Learning secondary mathematics with technology: Exploring the complex interrelationship between students' attitudes, engagement, gender and achievement. Computers \& Education, 52(3), 562-570. https:// doi.org/10.1016/j.compedu.2008.11.001

Batmaz, S. K. (2013). Tasarımda çeşitlenme sağlayan yöntemlerin günümüz mekan uygulamaları üzerinde incelenmesi (Doctoral Thesis). İstanbul Kültür Üniversity, Institute of Science and Technology/Department of Interior Architecture and Environmental Design.

Biggio, M., Vázquez, S. M., \& García, S. M. (2015). From representation to construction: A study of graphic skills in students newly admitted to architecture and design courses. Universidad de Buenos Aires, Argentina, technical paper. Australasian Journal of Engineering Education, 20(1), 95-102. https://doi.org/10.7158/D13-013.2015.20.1

Burmabıyık, A. (2015). Geometrik cisimlerin öğretimi için geliştirilen 3 boyutlu mobil uygulamalar hakkında öğrenci ve ögretmen görüşleri (Master's Thesis). Balikesir University, Institute of Science and Technology, Department of Computer and Teaching Technology Education.

Chalmers, F. G. (1981). Art education as ethnology. Studies in Art Education, 22(3), 6-14. https://doi.org/10.2307/1320067

Çivici, T., \& Kale, S. (2007). Mimari Tasarım Bürolarında Bilişim Teknolojilerinin Kullanımını Etkileyen Faktörler: Bir Yapisal Denklem Modeli [Factors That Influence Acceptance of Information Technologies in Architectural Design Firms: a Structural Equation Model]. In İnşaat Yönetimi Congress Proceedings (pp. 119-128). İstanbul: İMO İstanbul Subesi Maya publishing.

Çolakoğlu, B., \& Yazar, T. (2007). Mimarlik Eğitiminde Algoritma: Stüdyo Uygulamalari. Gazi Üniversitesi Mühendislik-Mimarlık Fakültesi Dergisi, 22(3), 379-385.

Donath, D., \& Regenbrecht, H. (1996, October). Using virtual reality aided design techniques for three-dimensional architectural sketching. In P. McIntosh, \& F. Ozel (Eds.), Design Computation, Collaboration, Reasoning, Pedagogy. ACADIA Conference Proceedings (pp. 201-212). Tucson, Arizona: University of Arizona publishing.

Duh, M., \& Zupančič, T. (2011). The method of aesthetic transfer-an outline of a specific method of visual arts didactics. Croatian Journal of Education, 13(1), 42-75.

Düzenli, T., \& Alpak, E. M. (2016). Peyzaj Mimarlığı Eğitiminde Doğaya Öykünme Yaklaşımının Yaratıcılık Üzerindeki Etkisi. Mimarlık ve Yaşam Dergisi, 1(1), 13-21. https:// doi.org/10.26835/my.266428 
Eceoğlu, A. (2012). Teknolojik Gelişmelerin Mimarlık Mesleğine Yansımaları ve Simülasyon Programları'nın Mekan Tasarımına Etkisi. The Turkish Online Journal of Design, Art and Communication, 2(2), 78-93. https://doi.org/10.7456/10202100/012

Ertan, E. (2016). İ̧ mimarlık ve çevre tasarımı sunumlarında simülasyon tabanl görsel efektlerin sağladığı olanaklar, kısıtlamalar ve çözüm öneriler (Master's thesis). Başkent Üniversitesi Sosyal Bilimler Enstitüsü.

Felleisen, M. (2001). How to design programs: an introduction to programming and computing. Cambridge, Massachusetts, London, England: MIT Press.

George, D., \& Mallery, M. (2010). SPSS for windows step by step: A simple guide and reference, 17.0 update ( $10^{\text {th }} \mathrm{ed}$.). Boston: Pearson.

Goldermans, S., \& Hoogenboom, M. (2001). GIS visualization the killer application. Geoinformatics, 12(2), 112-115. https://doi.org/10.6010/geoinformatics.12.112

Goldschmidt G., \& Smolkov, M. (2006). Variances in the impact of visual stimuli on design problem solving performance. Design Studies, 27, 549-569. https://doi.org/10.1016/j. destud.2006.01.002

Hughes, J. F., \& Foley, J. D. (2014). Computer graphics: principles and practice. United States of America, Willard, Ohio: Pearson Education, Inc.

Jones, J. C. (1992). Design methods. New York: Van Nostrand Reinhold

Kahraman, T. (2006). İstanbul Kentinde Kentsel Dönüșüm Projeleri ve Planlama Süreçleri. Planlama, 2, 93-101.

Kalay, Y. E. (2004). Architecture's new media: Principles, theories, and methods of computeraided design. Cambridge, Massachusetts, London, England: MIT Press.

Kalayc1, T. E. (2006). Yapay zeka teknikleri kullanan üç boyutlu grafik yazılımları için "Extensible $3 D^{\prime \prime}(X 3 D)$ ile bir altyapı oluşturulması ve gerçekleştirimi (Doctoral dissertation). Ege Üniversitesi.

Karadağ, D. (2011). Dijital tasarım ve üretim araçları ile mimaride malzeme kullanımının dönüşümü (Master's thesis). Yıldız Teknik Üniversitesi Sosyal Bilimler Enstitüsü.

Korkut, A., \& Özyavuz, M. (2016). Planlama Ve Tasarim Eğitiminde Teknoloji Altyapisinin Gerekliliği Üzerine Bir Araştirma. JOTAF/Tekirdağ Ziraat Fakültesi Dergisi, 13(2), 21-33.

Lauc, T., Kišiček, S., \& Bago, P. (2014). Multimedia Resources in an Online Course: Access and Usage with Respect to Sensory Modality. Croatian Journal of Education, 16(Sp. Ed. 3), 155-173.

Linn, M. C. (2000). Designing the knowledge integration environment. International Journal of Science Education, 22(8), 781-796. https://doi.org/10.1080/095006900412275

Maier, P. H. (1994). Raeumliches vorstellungsvermoegen. Wien: Lang.

Mayer, R. E., \& Sims, V.K. (1994). For Whom Is a Picture Worth a Thousand Words? Extensions of a Dual-Coding Theory of Multimedia Learning. Journal of Educational Psychology, 86(3), 389-401. https://doi.org/10.1037/0022-0663.86.3.389

McCullough, M., Mitchell, W. J., \& Purcell, P. (Eds.). (1990). The Electronic design studio: architectural knowledge and media in the computer era. Cambridge, Massachusetts, London, England: MIT Press.

O’Neill, D. K., \& Gomez, L. M. (1994). The Collaboratory Notebook: A Networked Knowledge-Building Environment for Project Learning. In Educational Multimedia and 
Hypermedia, June 1994, Proceedings of ED-MEDIA 94, World Conference on Educational Multimedia and Hypermedia. Vancouver, British Columbia, Canada.

Orhon, A. V. (2012). Akıllı malzemelerin mimarlıkta kullanımı. Ege mimarlık, 82, 18-21.

Özsel Akipek, F. (2004). Bilgisayar teknolojilerinin mimarlıkta tasarım geliştirme amaçlı kullanımları (Doctoral thesis). YTÜ Fen Bilimleri Enstitüsü.

Paar, P. (2006). Landscape visualizations: Applications and requirements of 3D visualization software for environmental planning. Computers, environment and urban systems, 30(6), 815-839. https://doi.org/10.1016/j.compenvurbsys.2005.07.002

Qing, L., \& Xin, M. (2010). A meta-analysis of the effects of computer technology on school students' mathematics learning. Educational Psychology Review, 22(3), 215-243. https://doi. org/10.1007/s10648-010-9125-8

Shaw, M. (1995). Comparing Architectural Design Styles. IEEE Software, 12(6), 27-41. https:// doi.org/10.1109/52.469758

Tagliabue, B. (2011). Conversando con. Benedetta Tagliabue. EGA. Revista de Expresión Gráfica Arquitectónica, 16(17), 15-27.

Tarakci Eren E., \& Var M. (2016, October). Education Process and Development of Environmental Design Project. In J. Gardia Laborda (Ed.), $7^{\text {th }}$ World conference on learning, teaching and educational leadership, WCLTA Conference Proceedings (pp. 129139). Budapest-Hungary: Awer center publishing.

Tjaden, B. J., \& Martin, C. D. (1995). Learning effects of CAI on college students. Computers \& Education, 24(4), 271-277. https://doi.org/10.1016/0360-1315(95)00031-G

Yakın, B. (2012). Tasarım Sürecinde Görsel Düşünme ve Görsel Anlatım Ilişkisine Analitik Bir Yaklaşım. Hacettepe Üniversitesi Güzel Sanatlar Enstitüsü, İç Mimari ve Çevre Tasarımı Anasanat Dalı/ İç Mimarlık Sanat Dalı. Ankara.

Yildirim, T., \& Yavuz, A. O. (2012). Comparison of traditional and digital visualization technologies in architectural design education. Procedia-Social and Behavioral Sciences, 51, 69-73. https://doi.org/10.1016/j.sbspro.2012.08.120

Yilmaz, S., Mumcu, S., \& Düzenli, T. (2017). Examining the Academic Success of the Students in Drawing Techniques Course: The Case of Freshmen in Landscape Architecture. European Online Journal of Natural and Social Sciences, 6(3), 406-416.

\author{
Emine Tarakci Eren \\ Karadeniz Technical University, \\ Department of Landscape Architecture \\ 61080, Trabzon, Turkey \\ eminem tarakci@hotmail.com
}




\section{Tugba Düzenli}

Karadeniz Technical University,

Department of Landscape Architecture

61080, Trabzon, Turkey

tugbaduzenli@gmail.com

\section{Serap Yilmaz}

Karadeniz Technical University,

Department of Landscape Architecture

61080, Trabzon, Turkey

serapyilmaz@ktu.edu.tr 


\section{Usporedba uporabe tradicionalnih i digitalnih tehnika vizualizacije u obrazovanju za dizajn za okoliš}

\section{Sažetak}

Brzi napredak računalne tehnologije omogućio je uporabu novih tehnologija u profesionalnim disciplinama kao što su likovna umjetnost, dizajn, arhitektura $i$ prostorno planiranje u kojima se dominantno oslanjamo na vizualizaciju. Preciznije, vizualizacija je potreba. Medutim, primjena tradicionalnih alata za dizajn i za tehnike grafičkog prikazivanja, skiciranja, iscrtavanja planova, profili, perspektive na papiru i izrada modela još uvijek se koriste u arhitekturi okoliša, arhitekturi, unutarnjoj arhitekturi ili u granama koje ovise o planiranju. Digitalne tehnologije, s druge strane, koriste se kao dodatni alati. Cilj ovoga rada je odrediti koje se metode dominantno koriste u različitim fazama u studiju dizajna za okoliš u obrazovanju za arhitekturu okoliša te usporediti razvijene programe za vizualizaciju. U tom kontekstu određena je razina zadovoljstva studenata s tim metodama. Istraživanje je provedeno sa studentima s Odjela za arhitekturu okoliša pri Sveučilištu Karadeniz Technical University (KTU). Rezultati istraživanja pokazali su da su razine zadovoljstva studenata arhitekture s digitalnim tehnologijama više u usporedbi s tradicionalnim metodama zbog uvjeta i superiorne kvalitete koju nude digitalne tehnologije.

Ključne riječi: tradicionalna i digitalna vizualizacija; studio dizajna za okoliš; tehnologija, razina zadovoljstva.

\section{Uvod}

Metode poučavanja znanstveno su i eksperimentalno dokazani načini učinkovite komunikacije između akademika i studenata u procesu transfera i usvajanja znanja i vještina, razvijanja kompetencija i podupiranja svih drugih razvojnih potencijala osobnosti u učenju i poučavanju (Duh i Zupančič, 2011). U stoljeću u kojemu živimo, u stoljeću rasprostranjene uporabe informacijske tehnologije, njezina uporaba $u$ području obrazovanja također se povećava s obzirom na napredak u učinkovitosti i prilikama koje te tehnologije stvaraju (Korkut i Ozyavuz, 2016; Mc Cullough i sur., 1990). Računala su korisna jer apstraktne pojmove čine konkretnima na ekranu te 
potiču proces učenja (Baki, 2002). Štoviše, mnoga recentna istraživanja dokazala su da računalo ima pozitivan utjecaj na učenje učenika (Barkatsas, Kasimatis, i Gialamas, 2009; Qing i Xin, 2010; Tjaden i Martin, 1995). Revolucija u digitalnoj tehnologiji zamjetno je promijenila i tradicionalne oblike crtanja (Yıldırım, Özen, i İnan, 2008). Uočeno je da su proizvodi izrađeni uporabom digitalne tehnologije izrazito nalikovali stvarnosti. To se odnosi na proizvode izrađene uporabom softvera u svim disciplinama dizajna a posebno $\mathrm{u}$ arhitekturi okoliša, u usporedbi s proizvodima koji su dobiveni tradicionalnim metodama (Akipek, 2004; Colakoğlu i Yazar, 2007; Nailer i Castle 2012; Orhon, 2012; Yllmaz i sur., 2017). Međutim, digitalne metode imaju i svoje nedostatke kada ih usporedimo s tradicionalnim metodama.

Komponente i računalni programi koji su razvijeni računalnom tehnologijom postali su bitni alati za dizajnere u izradi vlastitih 3D zamisli (Aybar, 2015; Burmabiyık, 2015; Chalmers, 1981; Karadağ, 2011). Nadalje, vizualna produkcija kreirana uz pomoć digitalne tehnologije bila je poželjnija jer je vrlo bliska stvarnosti, lako se može dugoročno pohraniti, prenijeti i prikazati. Tehnike digitalne vizualizacije koriste se kada su tradicionalne metode nedostatne. Stoga, uporabu digitalne vizualizacije ne bi trebalo odvajati u odnosu na uporabu tradicionalnih metoda. Percepcija otvorenih prostora upotrebom tehnika digitalne priče, pojam razmjera, prezentacija podražaja poput svjetla, sjene i vremena mogli bi proizvesti važne rezultate. Drugim riječima, elementi dizajna u projektima dizajna za okoliš često obuhvaćaju živuće elemente poput biljaka. Biljke su živući elementi, one rastu i tijekom vremena se mijenjaju. Te promjene koje će se s vremenom zamijetiti u projektima, iskazane su kroz četvrtu dimenziju. Animacije koje bi se mogle kreirati koristeći se digitalnom narativnom tehnikom mogle bi uvesti koncept vremena u projekte dizajna za okoliš. Kod tradicionalnih metoda ta je mogućnost znatno smanjena. Za razliku od tradicionalnih metoda alati poput računala, printera i programa potrebni su kako bi se iskoristile spomenute tehnike. Vizualizacijski softver preferira se zbog prednosti u uštedi vremena, smanjenju troškova, lakoći uređivanja, lakoj pohrane podataka, mogućnosti crtanja bez grešaka, brzoj produkciju slika i lakom generiranju novih mogućnosti (Eceoğlu, 2012; Kalayc1, 2006; Mayer i Sims, 1994; Uğur i Özgür, 2003). Nadalje, važno je razlučiti digitalno učenje od osjetilnih modaliteta (informacija vidom, sluhom, njuhom, dodirom i okusom) koji se odabiru za metode poučavanja (Clark i Feldon, 2005; Lauc i sur., 2013).

Kada govorimo o obrazovanju u području dizajna, prvo što nam se nameće jest unutarnji i vanjski dizajn (Batmaz, 2013). S obzirom na to da se vanjski prostor doživljava kao kombinacija drveća i zgrada, percipirati i dizajnirati prostor među tim elementima, točnije volumen, prilično je izazovno za one koji se time ne bave profesionalno. Strukovno obrazovanje i iskustvo potrebno je da bi se razumjeli volumen i prostor. Dobar dizajn za okoliš čuva i poboljšava zdravlje svih živućih organizama, a prednosti i nedostatci prirodnih događanja razmatraju se združeno. Uspješan dizajn treba uzeti u obzir veće izazove okoliša koji utječu na regiju, državu, 
pa čak i svijet. Takav pristup dizajnu često se naziva dizajn za okoliš (Booth i Hiss, 2008; Melby i Cathcart, 2002).

U obrazovanju za dizajn okoliša osposobljavanje započinje nakon što se identificira područje projekta. U toj fazi analize istraživanja studenti izlaze na teren koji istražuju i analiziraju, a u fazi dizajna provode istraživanje upotrebe terena, izrađuju dijagram funkcionalnosti, mjehurasti dijagram, formu, preliminarni dizajn, generiraju mogućnosti i precizna rješenja, a u fazi detalja odlučuju o podnim oblogama, biljkama, detaljima vezanim uz konstrukciju, odjele i visinu (Alpak i sur., 2017; Düzenli i Alpak, 2016; Kahraman, 2006; Tarakci Eren i Var, 2016). Studenti bi mogli te faze vizualizirati putem svojih ideja i promišljanja koristeći se mogućnostima kognitivne rotacije (Maier, 1994).

Vrste prikaza kojima se studenti koriste za vizualizaciju projekata dizajna za okoliš kategorizirane su u dvije skupine: tradicionalne i digitalne tehnike prikaza (AlKodmany, 1999; Ertan 2016; Goldschmidt i Smolkoy, 2006; Jones, 1992; Linn, 2000; Near, 2012; O-Neill, 1994; Paar, 2006; Shaw, 1994)

a) Tradicionalne tehnike prikaza su:

Dvodimenzionalni crteži na papiru (nacrt, presjek, visina)

Trodimenzionalni crteži na papiru (perspektiva)

Trodimenzionalni modeli

b) Digitalne tehnike prezentiranja

Dvodimenzionalni crteži izrađeni upotrebom digitalnih medija (nacrt, presjek, visina)

Trodimenzionalni modeli izrađeni upotrebom digitalnih medija

Animacija, realistične slike izrađene upotrebom digitalnih medija.

\section{Tradicionalne tehnike prikaza upotrijebljene u fazama dizajna za okoliš}

U procesu dizajna za okoliš apstraktne slike o rješenju problema oblikuju se u glavi dizajnera (arhitekta za okolišs, studenta). Prvi korak koji student napravi kada se koristi tradicionalnim tehnikama prikaza jest vizualizacija slika koristeći se papirom, olovkom ili modelima (Tablica 1). Crtež je vizualizacija cijelog ili dijelova arhitektonskog elementa primjenjujući nacrt, presjek, visinu ili perspektive, s obzirom na pravila tehničkoga crtanja.

\section{Digitalne tehnike prezentiranja upotrijebljene u fazama dizajna za okoliš}

Digitalne tehnike prezentiranja koje se koriste u procesu dizajna za okoliš arhitektonski je program koji se koristi za generiranje statičkih i pokretnih slika, program utemeljen na pikselima, vektorima i objektima (Donath i Regenbrecht, 1996; Felleisen, 2001; Hughes, 2014; Kalay, 2004). Program za vektorsko crtanje koristi se za izradu linijskih crteža. Taj se program u arhitektonskom dizajnu koristi za 
dvodimenzionalne crteže, trodimenzionalno modeliranje i trodimenzionalne obloge, usklađivanje materijala i osvjetljenje. Program za vektorsko crtanje, dvodimenzionalno crtanje (nacrt, presjek i visina) uključuje element linije. Linije mogu biti linearne ili zakrivljene. U projektima dizajna za okoliš često se koriste zakrivljene linije. Trodimenzionalni dizajn prostora modelira se kroz linije, čvorišta gdje se linije presijecaju i kod zatvaranja površinskih prostora koji su kreirani tim linijama. Uz 3D dizajn modela koje dobijemo upotrebom vektorskih programa za crtanje ili programa za objektno modeliranje, mogu se dobiti fotorealistični prikazi dizajna za okoliš koristeći se usklađivanjem tekstura dobivenih kamerom, osvjetljenjem i građevinskim materijalom (Tablica 2).

Tablica 1 i 2

\section{Materijali i metode}

U ovome su istraživanju, koristeći se tehnikom ankete, dobivene preferencije studenata. Upitnike je ispunilo 280 studenata upisanih na odjel Arhitekture okoliša Šumarskog fakulteta pri Kadiz Technical University. Od 280 studenata njih 265 su prvostupnici, a njih 15 su studenti u poslijediplomskim programima (master i doktorski studij). Studenti su odgovarali na sljedeća pitanja:

- kojim se računalnim programom koriste,

- koje tehnike prikaza preferiraju u fazama dizajna za okoliš,

- njihove procjene tradicionalnih i digitalnih tehnika prikaza s obzirom na vrijeme.,

- njihove procjene slika koje dobiju primjenom spomenutih tehnika s obzirom na sličnost $\mathrm{s}$ realnim, kvalitetom slike, lakoćom, dugoročnom pohranom i mobilnošću,

- i njihovim razinama zadovoljstva s navedenim metodama.

Tablica 3

\section{Rezultati}

\section{Rezultati o računalnom programu primijenjenom u obrazovanju za dizajn za okoliš}

Podatci iz anketa o upotrebi računala za dizajn za okoliš i prezentaciju pokazuju da se malen broj studenata (7\%) povremeno koristi računalom, a da se većina studenata (93\%) aktivno koristi računalom. Preferencije sudionika u ispitivanju o programu kojim se koriste u obrazovanju za dizajn prikazane su u prikazu 1. Uočeno je da svi studenti koji su sudjelovali u anketi preferiraju popularne programe kao što su AutoCAD, Photoshop i Sketchup u svom programu dizajn za okoliš, a neki studenti također preferiraju Archicad, 3ds Max i Lumion računalne programe.

Prikaz 1 


\section{Rezultati tehnika prezentiranja koje studenti preferiraju u različitim fazama dizajna za okoliš}

Danas postoji dogovor da su tradicionalne metode poučavanja nedostatne, a računalna tehnologija i programi počeli su se koristiti u obrazovanju pa je nastala tranzicija koja je spoj tradicionalnog i tehnološkog obrazovanja (Zor, 2006). Međutim, prije je uporaba računala u različitim fazama procesa poučavanja dizajna bila odraz ekonomskih i tehnoloških ograničenja koja su uglavnom vladala na fakultetima. Danas se tehnologijom koristimo sveobuhvatno. Odgovori studenata vezani uz tehnologiju kojom se koriste u obrazovanju za dizajn prikazani su na prikazu 2.

\section{Prikaz 2}

\section{Rezultati procjena tehnika s obzirom na vrijeme u radionici dizajna za okoliš}

Vrijeme koje studenti arhitekture okoliša provedu u materijalizaciji apstraktnog dizajna koji smisle varira ovisno o tehnici prikaza koju odaberu. Iz rezultata dobivenih anketiranjem na prikazu 3 prikazujemo odgovore studenata o količini vremena koje potroše u procesu dizajna u studiju.

Prikaz 3

Digitalni prikazi uglavnom se mogu dovršiti u kraćem vremenu u usporedbi s tradicionalnim metodama, no to nije slučaj u svim fazama procesa dizajna za okoliš. Kada se koriste tradicionalnim metodama za precizno i točno crtanje, studenti su sporiji. Uočeno je da studenti mogu brže crtati koristeći se digitalnim metodama jer računalni program rješava preciznost i točnost. Nadalje, uporaba predmeta (vrata, prozori, namještaj itd.) koji su prethodno kreirani i pohranjeni u datoteke s predmetima skraćuje vrijeme potrebno za crtanje. Na osnovi procjena studenata arhitekture okoliša tradicionalne tehnike prikaza zahtijevaju manje vremena za dovršavanje funkcijskog dijagrama, mjehurastog dijagrama, skice ili preliminarne faze dizajna u usporedbi s digitalnim prezentacijskim tehnikama. Upotrebom digitalnih prezentacijskih tehnika smanjuje se vrijeme istraživanja, anketiranja, analize, generiranja izbora, konačnog dizajna, tvrdog-mekog poda, sadnica, crtanja detalja gradnje i visine u usporedbi s tradicionalnim prezentacijskim tehnikama. Također, na osnovi studentske procjene faza dizajna za okoliš ustanovljeno je da tradicionalne tehnike prikaza imaju prednost s obzirom na to da skraćuju vrijeme dovršavanja funkcijskog dijagrama, mjehurastog dijagrama, skice i preliminarnih faza dizajna u usporedbi s digitalnim tehnikama prikaza. Digitalne tehnike prikaza povoljnije su s obzirom na to da skraćuju vrijeme potrebno za provođenje istraživanja, ispitivanja, analize i generiranja izbora konačnog dizajna, tvrdih ili mekih podnih obloga, sadnica, detalja izgradnje i visine odjeljaka u fazi crtanja u usporedbi s tradicionalnim oblicima prikaza. 


\section{Rezultati procjena tehnika s obzirom na sličnost slike dobivene u procesu dizajna za okoliš}

Sličnost u projektu dizajna za okoliš jest traženje gotovo realne simulacije putem slojeva materijala i dodavanjem svjetla i sjene u sam dizajn. U prikazima dobivenim tradicionalnim metodama, materijal i efekti svjetla i sjene u dvodimenzionalnim crtežima mogu se prikazati samo sjenčanjem ili slikanjem. U 3D crtežima i modelima koriste se pomoćni alati koji dodaju razne teksture materijala. Kod digitalnih metoda materijal se ne može dodati u dvodimenzionalnim crtežima dizajniranima koristeći se vektorskim programima, ali trodimenzionalni modeli daju uspješne rezultate s obzirom na to da dopuštaju dodavanje materijala, svjetlo i pozadinu (objekte poput drveća, ljudi, neba).

Studenti su procijenili digitalne i tradicionalne metode prikaza za svaku fazu u dizajnu za okoliš koristeći se ljestvicom od 1 do 5 ( 1 vrlo slabo, 2 slabo, 3 osrednje, 4 dobro, 5 vrlo dobro). Na taj se način izračunala aritmetička sredina. Rezultati procjene studenata arhitekture okoliša o metodi koja najzornije prikazuje realno stanje u različitim fazama dizajna za okoliš prikazani su na prikazu 4. Rezultat pokazuje da studenti smatraju da slike dobivene digitalnim metodama daju realniji prikaz.

\section{Prikaz 4}

\section{Rezultati s obzirom na "lakoću dugotrajne pohrane" i „pokretljivost i izražajnost" prikaza dobivenih u procesu dizajna za okoliš}

Pohrana je mogućnost pohrane slika (informacija) vezanih uz dizajn. S obzirom na slike i perspektive koje su nastale tradicionalnim metodama na papiru, kao i s obzirom na to da se ti modeli lako potroše, njima je potreban veliki skladišni prostor. Studenti arhitekture okoliša preferiraju digitalne metode jer se dobivene slike skladište u „bitovima”.

Pokretljivost i izražajnost povezani su s dizajnom videa ili animacije u modelima dizajna za okoliš, 2D i 3D prikazima. Neki faktori poput brzine prijelaza između scena, stila snimanja, kadra mogu se namjestiti. Što su više 2D i 3D prikazi izrađeni tom metodom bliži stvarnosti, to su impresivnije animacije ili videouradci. Stoga se digitalne metode smatraju uspješnijima s obzirom na pokretljivost i izražajnost kada to procjenjuju studenti arhitekture okoliša. Studenti su na skali od 1 do 5 (1 vrlo loše, 2 loše, 3 neutralno, 4 dobro, 5 vrlo dobro) procijenili digitalne i tradicionalne metode koje se koriste u dizajnu za okoliš s obzirom na lakoću i dugoročnu sposobnost pohrane, pokretljivost i izražajnost. Aritmetička sredina njihovih odgovora i grafički prikaz vide se na prikazu 5.

Prikaz 5 


\section{Rezultati razine zadovoljstva studenata o tehnikama koje se koriste u fazama dizajna za okoliš}

U provedenim anketama studenti su izrazili nezadovoljstvo tradicionalnim metodama jer te metode zahtijevaju puno vremena i truda, a rezultiraju lošom kvalitetom prikaza, imaju ograničenu sličnost sa stvarnošću i teško se revidiraju i stvaraju nove mogućnosti $(1,83)$. Međutim, studenti su izjavili da su zadovoljni digitalnim metodama zbog brzine, vremenskog zahtjeva, raznovrsnosti i kvalitete prikaza te su iskazali zadovoljstvo tom metodom $(3,59)$. Studenti su procijenili metode na osnovi projekata dizajna za okoliš koje su izradili tijekom svog obrazovanja koristeći se tradicionalnim i različitim digitalnim medijima (Prikaz 6). Procjene su radili na ljestvici od 5 stupnjeva ( 1 vrlo loše, 2 loše, 3 neutralno, 4 dobro, 5 vrlo dobro). Procjene utemeljene na kriterijima za svaku prezentacijsku metodu prikazani su na prikazu 6 .

\section{Prikaz 6}

\section{Rezultati usporedbe zadovoljstva metodama s obzirom na "Ilaku pohranu“ i „pokretljivost - izražajnost"}

U ovome dijelu prikazuju se rezultati zadovoljstva upotrebe tehnika prikaza s obzirom na „laku pohranu” $i$,pokretljivost-izražajnost” prikaza dobivenih navedenim tehnikama.

Prikazane su varijanca i vrijednosti asimetrije-spljoštenosti odgovora studenata vezanih uz prikaze dobivene nakon što su prikazane tehnike. Kod procjene lakoće pohrane, gibanja i izražajnosti određeni su asimetrija (lakoća: 0,062; pokretljivost: 0,022; zadovoljstvo: 0,64) i spljoštenost (lakoća: -1,825; pokretljivost: -1,957; zadovoljstvo: -1,987). George i Mallery (2010) izjavili su da takve vrijednosti pokazuju normalnu distribuciju unutar raspona vrijednosti $+2,00$ i -2,00. Prema tome, vrijednosti asimetrije i spljoštenosti u ovome istraživanju ukazuju na to da su podatci u normalnoj distribuciji.

Primjenom ANOVA testa pokazalo se da je zadovoljstvo tehnikama učinkovito kod prikaza koje su smatrali „lakima za pohranu” i „pokretljivost - izražajnost” (Tablica 4). Međutim, karakteristika „pokretljivost - izražajnost” prikaza više je doprinijela zadovoljstvu nego primjerice karakteristika „lakoća pohrane” prikaza.

Tablica 4

\section{Zaključci}

Kao i u svakom drugom području, danas se digitalna tehnologija koristi intenzivno i u području arhitekture okoliša. Posljedica je toga da digitalne tehnologije imaju važnu ulogu u obrazovanju za arhitekturu okoliša. Te tehnologije koriste se u kombinaciji s tradicionalnim metodama prikazivanja dizajna. Na Sveučilištu Karadeniz Technical, Odsjeku za arhitekturu okoliša, tradicionalne i digitalne metode prezentiranja koriste se u nekoliko kolegija uključujući radionice dizajna za okoliš. Kod obrazovanja za dizajn za okoliš postoje prednosti digitalnih prezentacijskih metoda u usporedbi s tradicionalnim prezentacijskim metodama. 
Izrada i revidiranje prikaza ostvaruje se u kraćem vremenu primjenom digitalnih medija $\mathrm{u}$ usporedbi s tradicionalnim metodama. Mnoge se mogućnosti mogu izraditi s puno manje truda koristeći se digitalnom metodom u usporedbi s tradicionalnim metodama. Isti model izrađen računalno može se koristiti za izradu dvodimenzionalnih slika, fotorealističnih prikaza, animacija i „prohodnih” simulacija. Tehnike digitalnog prikaza daju više uspješnih rezultata kod izražavanja dodataka poput trodimenzionalnog prikaza, percepcije prostora, razmjera, teksture, sjene, svjetla i vremena odnosno tamo gdje su tradicionalne metode nedostatne. Napredniji modeli mogu se lako izraditi s digitalnim modelima u usporedbi s tradicionalnim metodama poput crtanja, modeliranja. Tako se omogućuje interaktivno dijeljenje informacija. $\mathrm{Za}$ razliku od tradicionalnih metoda prikaza činjenica da su računalno generirani modeli trodimenzionalni i da se mogu promatrati iz željenoga ugla stvara veliku prednost. Osposobljavanje primjenom tradicionalnih metoda prikazivanja traje duže nego osposobljavanje primjenom računala i nalaže više sati pouke u rasporedu predavanja. Usporedba tradicionalnih i digitalnih alata za prikazivanje preferencija jedne prezentacijske tehnike nad drugom za vrijeme studija dizajna za okoliš na Sveučilištu Karadeniz, Odsjeku za arhitekturu okoliša pokazuje da se tradicionalne metode preferiraju kod funkcijskih dijagrama, mjehurastih dijagrama, skica i u preliminarnim fazama dizajna u radionici za dizajn za okoliš, a da se digitalne prezentacijske tehnike preferiraju kod istraživanja, ispitivanja, analize, generiranja mogućnosti, konačnog dizajna, nacrta, izbora mekih-tvrdih podova, sadnica, detalja izrade, u fazama koje prikazuju presjek i razine visine.

Zaključno, uočeno je da je prijelaz na primjenu informacijskih tehnologija u obrazovanju za arhitekturu okoliša, točnije dizajn za okoliš obavezan proces. Nadalje, bitan je zaključak činjenica da su i tradicionalne tehnike prezentiranja potrebne za primjenu digitalnih tehnologija u procesu vizualizacije dizajna za okoliš. $\mathrm{Na}$ osnovi procjena studenata tradicionalne metode preferiraju se i koriste većinom u početnim fazama projekata u radionici dizajna za okoliš. Tradicionalne su tehnike vizualizacije crtanje rukom, a digitalno crtanje podrazumijeva crteže izrađene primjenom programa za crtanje. Važno je započeti proces učenja dajući studentu mogućnost da se izrazi crtanjem rukom (Biggio i sur., 2015; Tagliabue, 2011). S obzirom na to da je pokret rukom praćen okom za vrijeme crtanja, ostvaruje se bolja koordinacija mozak-ruka. Studenti tako bolje internaliziraju crteže posredstvom osjeta dodira; studentima bi bilo lakše izraditi trodimenzionalne prikaze iz vlastitih ideja te ih rotirati u glavi (Biggio i sur., 2015; Tagliabue, 2011). Međutim, kada crtamo u digitalnom mediju, internalizacija koja se stvara osjetom dodira ostaje nedovršena. Stoga je crtež iz digitalnog medija nedovoljan za usvajanje vještina prikazivanja i trodimenzionalnog viđenja koje su potrebne za razvoj studenata (Biggio i sur., 2015; Tagliabue, 2011). Drugim riječima, u radionici dizajna za okoliš proces započinje primjenom tradicionalnih tehnika prikaza nakon čega slijedi primjena digitalnih tehnika koje se primjenjuju sve učestalije uslijed veće potrebe za detaljima. 